\title{
Competition, Work Rules and Productivity
}

\author{
Benjamin Bridgman*
}

Bureau of Economic Analysis

June 2011

\begin{abstract}
More competitive markets are associated with higher productivity. This paper examines productivity in markets with market power and restrictive work rules: rules that induce wages to be paid for non-productive labor hours. It develops a theoretical model to explain why workers would want restrictive work rules and how competition leads to their reduction. I model a monopoly firm whose workers dictate wages and work rules. Work rules allow workers to maintain both high levels of employment and wages. Competition reduces work rules and increases productivity by lowering mark-ups. The theoretical findings are consistent with the empirical literature on the impact of increasing competitive pressure on productivity.
\end{abstract}

\footnotetext{
${ }^{*}$ This paper was begun prior to joining BEA. I thank Berthold Herrendorf, Jim Schmitz and participants at the 2010 LAEF Growth and Development conference for comments. The views expressed in this paper are solely those of the author and not necessarily those of the U.S. Bureau of Economic Analysis or the U.S. Department of Commerce. Address: Department of Commerce, Bureau of Economic Analysis, Washington, DC 20230. email: Benjamin.Bridgman@bea.gov. Tel. (202) 606-9991. Fax (202) 606-5366.
} 


\section{Introduction}

More competitive markets are typically associated with higher productivity. (See Aghion \& Griffith (2005) and Van Reenen (2010) for surveys of the evidence.) There are a number of cases where an increase in competition led to a jump in productivity. For example, Schmitz (2005) documents enormous increases in labor productivity in U.S. iron ore mining after low cost Brazilian producers entered the market. Similar results have been found in coal mining (Parente \& Prescott 2000), international iron ore mining (GaldonSanchez \& Schmitz 2002), Brazilian oil extraction (Bridgman, Gomes \& Teixeira 2011) and U.S. cement (Dunne, Klimek \& Schmitz 2009). (See Holmes \& Schmitz (2010) for a surveys of this literature.) These gains are due largely to improvements at existing firms and are not due to the reallocation of inputs to more productive firms. In each of these cases, there was neither a new nor old, unadopted technology that was implemented to explain the increase. These studies argue that productivity improved when restrictive work rules, those that induce wages to be paid for non-productive labor hours, were eliminated. Schmitz (2005) finds that the number of job categories declined in U.S. iron ore mines when Brazilian ore entered the U.S. market. When the market for U.S. steel makers collapsed in the 1980s as foreign producers entered the market, plant managers at U.S. Steel began to violate the work rules in the contract to increase productivity (Hoerr 1988).

Why does competition reduce restrictive work practices and increase productivity? Economic theory typically predicts that productivity should increase when a firm's

market is expanding since the benefits of reducing costs are higher when spread across a larger market. For example, see Desmet \& Parente (2010), Vives (2008) and Bai \& Herrendorf (2008). Therefore, it is puzzling that productivity should jump when a firm's market is being squeezed by new competitors.

An exception is Holmes, Levine \& Schmitz (2008), which predicts that a monopolist will adopt new technology when demand is low due to start-up delays. They explicitly discuss work rules and suggest that firm owners will fight to remove work rules when demand is low since doing so risks a shutdown due to strong opposition from labor. Conflict over this issue has led to significant labor strife, including lengthy strikes and lockouts. Restrictive work rules must accomplish a goal that is valuable to workers for 
them to fight to protect them even in dire circumstances.

A typical rationale for these rules is to maintain employment. Indeed, Eberts \& Stone (1991) find that unionized firms increase the use of labor relative to other inputs. However in standard models, more efficient firms pay higher wages and employ more workers. If workers care about total employment as well as wages, as in Johnson (1990), a union may trade off higher wages for employment 1 . This theory does not generate genuinely restrictive work rules since workers do not want labor resources wasted. Another explanation is that there is a disutility to working, and work rules impose downtime giving the worker more leisure (Kahn \& Reagan 1993). This explanation begs the question why workers do not work all the hours they are on the clock in exchange for higher wages and enjoy their leisure away from the workplace, where leisure is presumably more enjoyable. It also does not explain why workers are only willing work more strenuously when the industry is under distress.

This paper develops a theory to explain why workers would want restrictive work rules and why competition reduces them. I study a model economy with a monopoly industry whose workers care about both total employment and wages. The incumbent workers can dictate wages and technology. The workers wish to employ all incumbent workers and drive up wages. There are demand shocks for the monopoly industry's product. I examine the outcomes of the model with and without competition. I also examine how work rules can induce resistance to new technology.

If workers care about both employment and wages, they will want restrictive work rules that take the form of a fixed cost. Without work rules, increasing employment comes at the cost of reducing wages. Restrictive work rules in the form of a fixed labor cost generate a source of labor demand to counteract the wage effect. If the additional hours were used in production, the firm would have to reduce prices to generate demand for the extra production. The workers prefer to waste some work hours to limit production and keep monopoly profits high. This result obtains even through workers do not value leisure, so any hours not used in production are a pure waste.

Competition leads to the reduction of restrictive work rules. When new competi-

\footnotetext{
${ }^{1}$ MaCurdy \& Pencavel (1986) find evidence that the typesetters union sought to maintain employment, not just increase wages.
} 
tors who can sell below the monopoly price enter, mark-ups are reduced. Maintaining the monopoly level work rules and wages would reduce profitability to the point of driving the firm out of business. Therefore, some combination of wages and work rules must fall to keep the firm in business. I show that increasing competition reduces restrictive work rules. In turn, productivity increases.

I also examine the impact of demand shocks on work rules. Under normal circumstances, the workers can find employment for all its members and still charge a wage premium. In a small downturn, the wage premium that is feasible is reduced but employment can be maintained. In this case, there are wage concessions, but no concessions on work rules. This finding is consistent with the "concession bargaining" literature that finds that wage concessions occur in industries with a high degree of market power and are linked with industry performance.

In severe downturns, there is insufficient surplus to pursue both goals. Even without a wage premium, work rules would drive the firm out of business. Therefore, the workers adjust work rules to keep the firm in business. They are only willing to adjust work rules if they know the firm is on the verge of closing.

Work rules can also have the effect of inducing resistance to new technology. Higher productivity increases demand for labor at a given wage, but also reduces the power of work rules to increase employment. When labor share is small or when demand is elastic, the work rule effect is stronger and employment would fall if the new technology was adopted. The union will only allow the adoption of the new technology if it is allowed to impose more work rules to maintain the employment that would otherwise be lost.

This paper is part of a theoretical literature examining productivity and labor unions, including Acemoglu, Aghion \& Violante (2001) and Dowrick \& Spencer (1994). Other papers have investigated the impact of labor unions on the decision to outsource work (Holmes \& Snider 2011). This paper differs from previous work in that it analyzes unproductive work rules.

A related theoretical literature, drawing on the work of Olson (1982), has developed to explain why technological improvements are blocked 2 . New technologies impose

\footnotetext{
${ }^{2}$ See Parente \& Prescott (1999), Holmes \& Schmitz (1995), Krusell \& Ríos-Rull (1996) and Herrendorf \& Teixeira (2010).
} 
costs on incumbent producers and certain frictions prevent those who benefit from higher productivity from compensating those who suffer costs. These frictions can be a lack of commitment to future payments (Kocherlakota 2001), a change in relative bargaining power (Acemoglu 2003), informational frictions (Mitchell \& Moro 2006), or inability of "winners" to organize (Bridgman, Livshits \& MacGee 2007). This paper differs in that it examines why an existing technology would be operated inefficiently rather than why a new technology would be blocked.

\section{$2 \quad$ Work Rules}

Restrictive work rules have been a feature in many industries in the United States, including transportation, steel, mining, automobile manufacturing and newspapers. While work rules are imposed for a number of reasons, a number of them are restrictive, in that they lead to paid labor hours that do not produce output. This section provides evidence of such work rules.

At its most extreme, there are work rules requiring jobs that produce no output, sometimes referred to as featherbedding. Examples of this include the "witnesses" on bulk loading in Pacific ports. When shipping of bulk goods, such as grain, shifted from loading individual bags to using gravity to pour it into ships, work rules required a gang of longshoremen to watch the loading (Hartman 1969). There were referred to as witnesses since all they did was watch the loading without working at all. Another example is firemen on diesel trains. Firemen had been required on coal fired steam trains to tend the engine. This job was no longer necessary after the conversion to diesel power, but the contract required that engines have a fireman.

A common variety of wasteful work rule is limited substitutability of workers across multiple work categories. Such rules increase the amount of time on the job that a worker in not producing. In the West Coast longshore industry, there were a number of such rules. Once a gang was called out to a ship, it had to be paid for a full shift even if it did not work the full time and could not be moved to a different ship. Japanese-owned U.S. car plants have fewer job categories and are more productive than their U.S.-owned counterparts. Mitchell \& Stone (1992) attribute lower productivity in union sawmills in 
part to limited substitutability across job categories. Hoerr (1988) discusses how the lack of substitutability across jobs in the U.S. steel industry led to so much downtime that reading and sleeping on the job was common. Schmitz (2005) documents the decline in the number of work categories in the iron ore industry after the crisis. Ichniowski (1984) finds that the number of pages in a labor contract is negatively correlated with productivity.

While many of these work rules are embodied in labor contracts, there are informal work rules. In the West Coast longshore industry, one practice was the "four on, four off" rule. Half the members of a gang would rest while the other half worked. (The name originates from a standard eight man hold loading gang). This practice persisted despite being explicitly banned by the labor contract. There were also informal maximum production limits. If a gang was getting ahead of its limit, they would delay calls for trucks to pick up cargo (Finlay 1987, Finlay 1988).

A crucial aspect of work rules for the theoretical results is they impose fixed costs of production. On the margin, the firm is using the technology efficiently but it has to pay for hours that are not used in production. It is true that many restrictive work rules are not strictly fixed costs, but are at least loosely related to output. The results require that the workers weaken the link between output and labor demand. A lot of the work rules generate downtime that is related to labor hired, but not in the linear way. For example, Schmitz (2005) documents that maintenance tasks at Minnesota iron ore mines were separated into a large number of classifications that only could be performed by a worker specialized in that classification. A mine needed to employ at least one worker in each classification, regardless of the ore produced. After the mines were subject to competition, the number of classifications dropped from nearly 30 to less than 10 . The fixed cost assumption is a mathematically convenient way of breaking the link between labor demand and production that allows for analytical solutions to the model.

The work rules that the paper studies do not cover all possible work rules. In contrast, there are work rules that increase costs but do not affect production, such as requiring the employer to provide hard hats. Rules may reduce productivity to accomplish another goal, such as worker safety or environmental protection. 


\section{Model}

\subsection{Households}

There is a continuum of households indexed by $i \in[0,1]$. Each household is endowed with one unit of labor $n_{i}$. There is a continuum of goods $c_{j}$, indexed by $j \in[0,1]$. Preferences are represented by the utility function:

$$
U=\left[\int_{0}^{1} c_{j}^{1-\rho} \theta_{j} d j\right]^{\frac{1}{1-\rho}} .
$$

where $\theta_{j}$ is a demand shock for good $j$ and $\rho \in(0,1)$. Demand shocks only vary in industry 1 . For $j \in[0,1), \theta_{j}=1$.

\subsection{Technology}

Goods are produced using labor and capital according to the Cobb-Douglas production function:

$$
c_{j}=\left(k_{j}\right)^{\alpha}\left(A_{j} n_{j}\right)^{1-\alpha} .
$$

In all sectors, capital is hired at the competitive rental rate $r$. Each household owns a representative portfolio of shares in all firms and own the capital.

As in Chari \& Hopenhayn (1991), more productive vintages of the technology arrive exogenously and can be costlessly adopted by firms. The productivity parameter $A_{j}$ for vintage $\nu$ is given by $A_{j}=\gamma^{\nu}$ where $\gamma>1$.

\subsection{Monopoly Sector}

The technology to produce good 1 is operated by a monopolist. Workers in the monopoly industry are represented by a union, whose membership is all incumbent workers $\left(\bar{n}_{1}\right)$. When a worker exits the industry, she is no longer a member of the union.

The union can impose work rules on the production process of the monopoly firm, so that the production function becomes:

$$
c_{1}=\left(k_{1}\right)^{\alpha}\left(A_{1} n_{1}-\kappa\right)^{1-\alpha}
$$


where $\kappa>0$.

The union sets the wage, work rules and vintage of the technology used by the firm. Similar to Pissarides (1986), it uses these instruments to maximize wages of its members, treating its members symmetrically.

The union's preferences are lexicographical: It wishes to maximize employment if employment is less than $\bar{n}_{1}$, the monopoly industry's incumbent workers. Once $n=\bar{n}_{1}$, it maximizes wages.

Given wage $w_{1}$, work rules $\kappa$ and the technology $A_{1}$ the union selects, the monopolist chooses the amount of capital to rent and sets $p_{1}$ to maximize profits.

\subsection{Foreign Sector}

There is a foreign sector that can sell same good as monopoly sector at price $p^{F}$. This sector can supply to whole market at this price. As a baseline, the foreign sector is not competitive: $p^{F}>p_{1}$. If it is competitive, the domestic monopoly prices according to Bertrand competition $p^{F}=p_{1}$. The severity of competition is indexed by $p^{F}$. A lower $p^{F}$ means more severe competition. The interpretation is that increasing competition represents falling trade barriers or the entry of low cost producers.

\subsection{Goods and Labor Markets}

All goods outside of the monopoly sector $(j \in[0,1))$ are produced by competitive firms, where wages, rental rates and prices are set competitively. Competitive firms maximize profits taking prices $p_{j}$ and wages $w_{j} j \in[0,1)$ as given and are not restricted from adopting new vintages.

\subsection{Timing}

The timing in the monopoly sector is as follows:

1. Demand parameter $\theta_{1}$ is realized.

2. Union sets wage/technology/work rule policy. 
3. Firm capital capital and sets price.

4. Production/consumption occurs.

\section{Equilibrium}

The state of the model at the beginning of the period is the measure of incumbent workers $\left\{\bar{n}_{j}\right\}_{j=0}^{1}$ and initial technologies $\left\{\bar{A}_{j}\right\}_{j=0}^{1}$ in each industry. Let $\mathcal{A}_{j}$ be the vintages of technology available for industry $j$.

Given prices and wages, households choose consumption to maximize $u$ subject to the budget constraint:

$$
\int p_{j} c_{j} d j \leq \int w_{j} d j
$$

The solution to this problem generates a demand function for the monopoly good $D\left(p_{1}\right)$.

The monopolist's problem is, given the wage, work rules and technology that it is allowed to use, to choose $p_{1}$ to solve:

$$
\begin{gathered}
\max _{p_{1}, k_{1}, n_{1}} \pi_{1}=p_{1} D\left(p_{1}\right)-w_{1} n_{1}-r k_{1} \\
\text { s.t. } \\
\begin{aligned}
D\left(p_{1}\right) & =\left(k_{1}\right)^{\alpha}\left(A_{1} n_{1}-\kappa\right)^{1-\alpha} \\
p_{1} & \leq p^{F}
\end{aligned}
\end{gathered}
$$

The solution to the firm's problem generates profits $\pi_{1}\left(w_{1}, A_{1}, \kappa\right)$ and labor demand $n_{1}\left(w_{1}, A_{1}, \kappa\right)$ that depend on the wage, work rules and technology selected by the union. If the firm cannot make non-negative profits, it does not operate.

The union's problem depends on whether there exists a union policy $\left\{w_{1}, A_{1}, \kappa\right\}$ that allows full employment. If so, the union sets the wage as high as is consistent with 
full union employment and non-negative firm profit. It solves:

$$
\begin{aligned}
& \max _{w_{1}, \kappa, A_{1}} w_{1} \\
& \text { s.t. } \\
& \pi_{1}\left(w_{1}, A_{1}, \kappa\right) \geq 0 \\
& n_{1}\left(w_{1}, A_{1}, \kappa\right) \geq \bar{n}_{1} \\
& A_{1} \in \mathcal{A}_{1}
\end{aligned}
$$

If not, the union's problem is to maximize employment at the wage of the outside option $w_{0}$. It sets work rules at the highest level that is consistent firm operating.

$$
\begin{aligned}
& \max _{w_{1}, \kappa, A_{1}} n_{1} \\
& \text { s.t. } \\
& \pi_{1}\left(w_{1}, A_{1}, \kappa\right) \geq 0 \\
& w_{1} \geq w_{0} \\
& A_{1} \in \mathcal{A}_{1}
\end{aligned}
$$

The definition of equilibrium is standard.

Definition 4.1. An equilibrium is goods prices $\left\{p_{j}^{*}\right\}_{j \in[0,1]}$, labor allocations $\left\{n_{j}^{*}\right\}_{j \in[0,1]}$, capital $\left\{k_{j}^{*}\right\}_{j \in[0,1]}$, wages $\left\{w_{j}^{*}\right\}_{j \in[0,1]}$, work rules $\kappa^{*}$ and consumption $\left\{c_{j}^{*}\right\}_{j \in[0,1]}$ such that:

1. Households solve their problem,

2. Firms solve their problem,

3. The union solves its problem,

4. Markets clear.

\section{Results}

This section first presents the solution to and results for the monopoly case unconstrained by competition. Then I introduce binding competition and compare the two cases. 


\subsection{Monopoly Solution}

Since we are concerned with the dynamics of the monopoly industry $j=1$, I will concentrate on a symmetric equilibrium in the competitive industries. There is an initial distribution of workers in each industry: $\left\{\bar{n}_{j}\right\}_{j=0}^{1}$. All competitive industries start with the same initial measure of incumbent workers. For simplicity, I set these quantities to one: $\bar{n}_{j}=\bar{n}_{j^{\prime}}=1$ for $j, j^{\prime} \in[0,1)$. I also assume they use the same technology, also normalized to one: $A_{j}=A_{j^{\prime}}=1$ for $j, j^{\prime} \in[0,1)$. The wages in these industries are given by $w_{j}=p_{j}(1-\alpha) \frac{y_{j}}{n_{j}}$ and the rental rate is given by $r_{j}=p_{j} \alpha \frac{y_{j}}{k_{j}}$. The price of good 0 is normalized to 1 . By symmetry, $p_{j}=1$ for all $j \in[0,1)$. Since labor and capital is mobile, $r_{j}=r$ and $w_{j}=w_{0}$ for all $j$. For convenience, I identify the quantities in the competitive industries by the subscript 0 .

The model is solved backward. Since the monopoly industry is atomistic, the wealth of the representative household is given by the wage and capital returns in the competitive sector. Wealth is $A_{0}=1$. Therefore, the household's demand is

$$
D\left(p_{1}\right)=\left[\frac{\theta_{1}}{p_{1}}\right]^{\frac{1}{\rho}}
$$

Given this demand and the wage and technology that the union sets and the rental rate of capital, the monopolist chooses labor, capital and price to maximize profits.

The solution to the firm's problem can be broken up into two parts. For a given price, the firm chooses capital and labor to minimize the cost of production for the associated level of output.

$$
\begin{aligned}
& \min _{k_{1}, n_{1}} w_{1} n_{1}+r k_{1} \\
& \text { s.t. } \\
& \left(\frac{\theta_{1}}{p_{1}}\right)^{\frac{1}{\rho}} \leq\left(k_{1}\right)^{\alpha}\left(A_{1} n_{1}-\kappa\right)^{1-\alpha}
\end{aligned}
$$

The solution to this problem generates labor and capital demand as a function of price. Capital and labor demand are respectively:

$$
k_{1}\left(p_{1}\right)=\left[\frac{\theta_{1}}{p_{1}}\right]^{\frac{1}{\rho}}\left(\frac{w_{1} \alpha}{A_{1} r(1-\alpha)}\right)^{1-\alpha}
$$




$$
n_{1}\left(p_{1}\right)=\left[\frac{\theta_{1}}{p_{1}}\right]^{\frac{1}{\rho}}\left(\frac{1}{A_{1}}\right)^{1-\alpha}\left(\frac{r(1-\alpha)}{w_{1} \alpha}\right)^{\alpha}+\frac{\kappa}{A_{1}}
$$

The monopolist sets price to maximize profits:

$$
p_{1}\left(w_{1}, r, A_{1}\right)=\left(\frac{w_{1}}{A_{1}}\right)^{(1-\alpha)}\left(\frac{1}{1-\rho}\right) r^{\alpha}\left[\left(\frac{\alpha}{1-\alpha}\right)^{1-\alpha}+\left(\frac{1-\alpha}{\alpha}\right)^{\alpha}\right]
$$

Assume that demand for the monopoly good is sufficient that full employment can be achieved at a wage above the competitive wage: $p^{*} \leq p^{F}$. The union selects wage, work rules and technology to maximize the wage subject to full employment and

not driving the monopoly firm out of business. The union will choose $\kappa$ and $w_{1}$ so that both constraints bind.

$$
w_{1}^{*}=A_{1}\left[\frac{\theta_{1}^{\frac{1}{\rho}}}{A_{1} \bar{n}_{1}}\left(\frac{1}{r^{\alpha}}\right)^{\frac{1-\rho}{\rho}}\left[\left(\frac{1-\alpha}{\alpha}\right)^{\alpha}(1-\rho)^{\frac{1}{\rho}} \Psi^{\frac{1}{\rho}}+\left((1-\rho)^{\frac{1-\rho}{\rho}}-(1-\rho)^{\frac{1}{\rho}}\right) \Psi^{\frac{1-\rho}{\rho}}\right]\right]^{\frac{\rho}{\alpha \rho+1-\alpha}}
$$

where

$$
\Psi=\frac{1}{\left(\frac{\alpha}{1-\alpha}\right)^{1-\alpha}+\left(\frac{1-\alpha}{\alpha}\right)^{\alpha}}
$$

Work rules are given by:

$$
\kappa^{*}=A_{1} \bar{n}_{1} \frac{\left((1-\rho)^{\frac{1-\rho}{\rho}}-(1-\rho)^{\frac{1}{\rho}}\right) \Psi^{\frac{1-\rho}{\rho}}}{\left(\frac{1-\alpha}{\alpha}\right)^{\alpha}(1-\rho)^{\frac{1}{\rho}} \Psi^{\frac{1}{\rho}}+\left((1-\rho)^{\frac{1-\rho}{\rho}}-(1-\rho)^{\frac{1}{\rho}}\right) \Psi^{\frac{1-\rho}{\rho}}}
$$

Adopting the new technology $A_{1}^{\prime}=\gamma \bar{A}_{1}$ raises wages, so if it is available the new technology is adopted.

\subsection{Rationale for Restrictive Work Rules}

The theory provides an explanation for why workers would want to build in wasteful work rules. Work rules provide an instrument to keep wages high without driving employment down.

Without work rules, the union can only affect employment (for a given level of technology) by adjusting wages. As wages fall, the firm demands more labor. Therefore, 
increasing wages comes at the cost of employment. This effect can be seen clearly from the firm's labor demand function:

$$
n\left(w_{1}, \kappa\right)=A_{1}^{\frac{(1-\alpha)(1-\rho)}{\rho}}\left(\frac{1}{w_{1}}\right)^{\frac{\alpha \rho+1-\alpha}{\rho}} \theta_{1}^{\frac{1}{\rho}}\left(\frac{1}{r^{\alpha}}\right)^{\frac{1-\rho}{\rho}}\left(\frac{1-\alpha}{\alpha}\right)^{\alpha}(1-\rho)^{\frac{1}{\rho}} \Psi^{\frac{1}{\rho}}+\frac{\kappa}{A_{1}}
$$

The union can counteract this effect by adding wasteful work rules since labor demand is increasing in work rules $\kappa$. When the union pushes up wages, it can counteract lower labor demand by increasing the wastefulness of the work rules.

This intuition carries over to the equilibrium allocations. In what follows, I compare the outcome of the model with a modified model where the union faces the additional constraint that it cannot use work rules $(\kappa=0)$. Equilibrium wages in the model are higher than in the case where the union cannot use work rules. This result is formalized in the following proposition.

Proposition 5.1. If the monopoly firm is unconstrained by competition $\left(p^{*} \leq p^{F}\right)$, wages with work rules $w_{1}^{*}$ are higher than wages without work rules $w_{1}^{N W R}$ and employment is the same: $n_{1}^{*}=n_{1}^{N W R}=\bar{n}_{1}$.

Proof. If the union did not have access to work rules as an instrument $\kappa=0$, the union chooses the wage such that $n_{1}^{N W R}=\bar{n}_{1}$. This wage is given by:

$$
w_{1}^{N W R}=A_{1}\left[\frac{\theta_{1}^{\frac{1}{\rho}}}{A_{1} \bar{n}_{1}}\left(\frac{1}{r^{\alpha}}\right)^{\frac{1-\rho}{\rho}}\left(\frac{1-\alpha}{\alpha}\right)^{\alpha}(1-\rho)^{\frac{1}{\rho}} \Psi^{\frac{1}{\rho}}\right]^{\frac{\rho}{\alpha \rho+1-\alpha}}
$$

Comparing the wage with work rules (equation 5.7) and equation 5.11, wages with work rules are higher $\left(w_{1}^{*}>w_{1}^{N W R}\right)$ if $(1-\rho)^{\frac{1-\rho}{\rho}}>(1-\rho)^{\frac{1}{\rho}}$. Simplifying, this condition becomes $(1-\rho)^{\rho}<1$. Since $\rho \in(0,1)$, the expression is true.

The logic of the result is unchanged under competition. As shown below, this result is true with binding competition.

The result does not rely on a disutility of work. The union selects work rules that reduce work effort even though the workers do not mind working harder. Extending the model to include leisure in workers utility would strengthen the results. Work rules would have the additional benefit of making work easier. 
Work rules take the form of a fixed cost. An alternative way of imposing work rules would be to directly reduce productivity parameter $A_{1}$. The union would not want to do so if the fixed cost is available. The fixed cost does not affect the firm's marginal pricing decisions. This fact can be seen by examining the pricing equation (Equation 5.6) and noting that $\kappa$ does not appear. Reducing $A_{1}$, raises the price which in turn reduces households' demand for the monopoly good and the labor that produces it. Without work rules, labor demand (Equation 5.10) is strictly increasing in $A_{1}$.

Another method of increasing employment would be for the union to force the firm to use $\bar{n}_{1}$ workers in production and set wages. Given access to work rules, the union would not want to maintain employment in this way. This plan yields higher output than under work rules, which requires lower prices and lower surplus. The union prefers work rules that are wasteful since they do not interfere with the monopoly firm's marginal pricing problem and yield the largest surplus.

In the model, there is a single monopoly firm. In examples of work rules given above, there are usually a number of firms. As long as the union can impose the same rules across firms and there is no entry, the results hold up. Suppose the monopoly was divided into two firms. Neither firm would wish to deviate from the monopoly price since it would lead to negative profits. As has been noted in the cartel literature, maintaining cooperative cartel behavior is easier when costs are similar (Vasconcelos 2005). In a number of cases, unions have explicitly pursued common wages and work rules across firms. As documented by Hoerr (1988), the United Steel Workers negotiated wages to be exactly the same in the eight largest firms in the U.S. basic steel industry, including the dominant firm U.S. Steel. Most smaller firms would use that same scale. Such unified contracts across firms were also found with port labor and coal mining.

\subsection{Impact of Work Rules on Productivity}

Productivity is reduced by work rules. Clearly, work rules lead to labor being wasted which will reduce productivity. 
Total factor productivity (TFP) is given by:

$$
\begin{aligned}
\ln (T F P) & =\ln (y)-\alpha \ln (k)-(1-\alpha) \ln (n) \\
& =\alpha \ln (k)+(1-\alpha) \ln (A n-\kappa)-\alpha \ln (k)-(1-\alpha) \ln (n)
\end{aligned}
$$

This expression simplifies to $(1-\alpha)(\ln (A n-\kappa)-\ln (n))$. Without work rules, this expression collapses to $(1-\alpha) \ln (A)$. For a given level of inputs, it is clear that TFP declines as work rules become more restrictive ( $\kappa$ increases). The source of inefficiency is not resistance to new technology (improvements in $A$ ) but the inefficient use of that technology. As shown above, the union does not want to reduce $A$. This calculation assumes that TFP is properly measured: The labor share used is the true value. The presence of market power will make labor shares observed in the data to deviate from the true values.

Since work rules introduce a fixed cost, the production function becomes increasing returns to scale. For a given $\kappa$, TFP falls if labor input falls. In the full employment equilibrium, labor input does not change so scale is not an issue. When full employment is not sustainable (the crisis equilibrium analyzed below), scale may impact TFP measurement.

Work rules $\kappa$ are higher when capital share is high and when demand is more inelastic ( $\alpha$ and $\rho$ are close to one). Using the work rules equation (Equation 5.9) and some tedious algebra, it can be shown that for a given $\alpha, A_{1}$ and $\bar{n}_{1}$, if $\rho^{\prime}>\rho$ then $\kappa^{*}\left(\rho^{\prime}\right)>\kappa^{*}(\rho)$. As similar result holds for $\alpha$ : if $\alpha^{\prime}>\alpha$ then $\kappa^{*}\left(\alpha^{\prime}\right)>\kappa^{*}(\alpha)$. Productivity is higher when labor share is higher and when demand is elastic.

When capital share is high, there is relatively little demand for productive labor. Most of the output is produced using capital. To employ all union members requires more work rules.

When demand is inelastic, a similar effect holds. The firm will choose a high price and produce very little, meaning little demand for productive labor. In addition, there are substantial rents for the union to capture using work rules. Setting high work rules allows the union to capture these rents while compensating for the low labor demand. Conversely, when demand is elastic, the firm cannot mark prices up much and demand for productive labor is relatively high. Therefore, work rules will be low. 
These results are consistent with the observation that the industries with the most restrictive work rules tend to be capital intensive industries and those with inelastic demand. Many of the examples given above are industries where both are true. For example, in the period when iron mining developed its work rules, steel could not be produced without iron ore. It is also a capital intensive industry.

\subsection{Wage Concessions}

Union's emphasis on protecting the employment of its members means that it will be willing to give wage concessions to maintain employment during downturns. Wages chosen by the union (Equation 5.7) are a linear function of the demand shock $\theta_{1}$. Equation 5.7 only applies when the union can still command a wage premium, so this analysis only applies when downturns are relatively small. Below I consider strong downturns, crises when a wage premium cannot be sustained.

This finding is consistent with findings of the concession bargaining literature. Freeman \& Kleiner (1999) find that unions drive up wages but not to the point that maintaining production (thus employment) is threatened. Henle (1973) documents a number of cases where union contracts were renegotiated in advance of their expiration date. Generally, unions accepted wage cuts during poor economic times in exchange for employment guarantees. Greenberg (1968) finds that union locals are willing to violate the wage terms of their master contract (accept lower wages) to preserve employment. Bastos \& Wright (2010) find that unions adjust wages down in response to currency appreciations.

The union does not give concessions on work rules. The union's work rule decision is not dependent on market conditions (Equation 5.9), again assuming that demand is high enough. Therefore, wages are cut but productivity is unchanged in minor downturns.

This finding also finds support in the data. Facing a serious decline in demand in the early 1980s, workers at the large steel companies cut wages but did not give any concessions on work rules. It was only when demand had fallen severely that concessions were made on work rules. For example, the Bethlehem Steel's Johnstown plant agreed to such concessions when half of the plant's workers were on layoff (Strohmeyer 1994). 


\subsection{Competition and Work Rules}

I now introduce binding competition to the monopoly sector. I show that competition reduces work rules and increases productivity.

There are two types of competition: crisis and non-crisis. Crisis competition is the case where $p^{F}$ is low enough that full employment and a wage premium cannot be maintained. Non-crisis competition is the case where $p^{F}$ is below the monopoly price but high enough that both full employment and wage premium can be maintained. In both cases, competition leads to increased productivity by reducing work rules. However, the mechanism is somewhat different in the two cases since the union is in different regions of its lexicographical preferences.

When comparing the equilibrium work rules for a set of parameters under monopoly and non-crisis competition, work rules are lower and productivity higher under competition. Let $\kappa(p)$ be the work rules associated with price $p$. Let $p^{C}$ be the cutoff price such that if $p^{F}<p^{C}$ a full employment equilibrium does not exist.

Proposition 5.2. Work rules under competition are lower than under monopoly: $\kappa\left(p_{1}^{*}\right)>$ $\kappa\left(p^{F}\right)$ where $p_{1}^{*}>p^{F}>p^{C}$.

Proof. Profits are negative under competition with monopoly wages and work rules. The union chooses $\kappa_{1}^{*}$ and $w_{1}^{*}$ to set profits equal to zero when the firm chooses profit maximizing price $p_{1}^{*}$. Since the firm's problem has a unique solution, any other price will lower profits. Since profit is decreasing in wages and work rules, the union must reduce at least one of these to satisfy the non-negative profit constraint: $\pi(w, \kappa) \geq 0$.

Work rules $\kappa$ must fall. Labor demand is given by:

$$
n\left(p, w_{1}, \kappa\right)=\left(\frac{\theta_{1}}{p}\right)^{\frac{1}{\rho}} \frac{1}{A_{1}}\left(\frac{r(1-\alpha) A_{1}}{\alpha w_{1}}\right)^{\alpha}+\frac{\kappa}{A_{1}}
$$

Since $n\left(p, w_{1}, \kappa\right)$ is decreasing in $p$ and $p_{1}^{*}>p^{F}, n\left(p^{F}, w_{1}^{*}, \kappa^{*}\right)>n\left(p_{1}^{*}, w_{1}^{*}, \kappa^{*}\right)=\bar{n}_{1}$. To reduce labor demand to satisfy the full employment constraint $\left(n\left(p_{1}^{F}, w_{1}, \kappa\right)=\bar{n}_{1}\right)$, either wage must increase or work rules must fall. Raising wages would violate the non-negative profit condition. Lowering work rules raises profits and lowers labor demand. Therefore, work rules under competition must be lower than under monopoly: $\kappa\left(p^{F}\right)<\kappa\left(p_{1}^{*}\right)$. 
Competition reduces the monopoly firm's profit. Therefore, if the union's policy under monopoly were used, the firm would make negative profits. To keep the firm in business, either wage or work rules must be adjusted downward. The reason it will not be wages is that the lower price loosens the union's full employment constraint. Lower prices mean more demand, hence more labor demand. The union can still employ all its members with fewer work rules (lower $\kappa$ ). Fewer work rules also improves the firm's profitability. While higher wages would also reduce labor demand back to just union members, profits would fall even more and drive the firm out of business.

Productivity is higher under competition compared to the unconstrained monopoly. From Equation 5.12, the TFP difference between competition $\left(T F P^{F}\right)$ and monopoly $\left(T F P^{*}\right)$ is:

$$
\begin{aligned}
\ln \left(T F P^{F}\right)-\ln \left(T F P^{*}\right) & =(1-\alpha)\left[\ln \left(A \bar{n}_{1}-\kappa^{F}\right)-\ln \left(\bar{n}_{1}\right)\right]-(1-\alpha)\left[\ln \left(A \bar{n}_{1}-\kappa^{*}\right)-\ln \left(\bar{n}_{1}\right)\right] \\
& =(1-\alpha)\left[\ln \left(A \bar{n}_{1}-\kappa^{F}\right)-\ln \left(A \bar{n}_{1}-\kappa^{*}\right)\right]
\end{aligned}
$$

Since $\kappa^{*}>\kappa^{F}, \ln \left(A \bar{n}_{1}-\kappa^{F}\right)-\ln \left(A \bar{n}_{1}-\kappa^{*}\right)>0$.

Since work rules are lower while employment is constant, fewer work hours are wasted. The firm is able to meet the increased demand for its product by placing more workers in production.

The impact of non-crisis competition on work rules and productivity is monotonic: Stronger competition, as measured by lower $p^{F}$, leads to lower $\kappa$. If $p_{1}^{*}>p^{F}>p^{F, I}>p^{C}$, then $\kappa\left(p^{F,}\right)<\kappa\left(p^{F}\right)$. The same logic as found in Proposition 5.2 holds. More competition lowers monopoly rents while increasing labor demand. Lower $\kappa$ places both of the union's constraints back at equality.

In the above analysis, the union can command both full employment and a wage premium. However, when competition is severe these twin goals cannot jointly be pursued. The union wishes to maintain as much employment as possible. To keep workers in the industry, it must set a wage that is competitive with alternative industries $\left(w_{1} \geq w_{0}\right)$ or workers will abandon the monopoly industry for employment in non-monopoly industries. It must still ensure that the firm makes sufficient profits so that it will operate in the monopoly sector. The union's problem shifts from maximizing wages subject to full employment to maximizing employment at the wage of the outside option. The union 
will set work rules at the highest level that is consistent with the firm operating in the monopoly industry.

The crisis work rules solution is:

$$
\kappa^{\text {Crisis }}=\frac{A_{1}}{w_{0}} \theta_{1}^{\frac{1}{\rho}}\left(p^{F}\right)^{\frac{1-\rho}{\rho}}-\left(\frac{A_{1}}{w_{0}}\right)^{\alpha}\left(\frac{\theta_{1}}{w_{0}}\right)^{\frac{1}{\rho}} r^{\alpha} \frac{1}{\Psi}
$$

In the crisis mode, more severe competition (lower $p^{F}$ ) induces fewer work rules. As a consequence, productivity improves with the severity of the crisis. From Equation 5.12, TFP is driven by the ratio of output from labor to labor input:

$$
\frac{A n-\kappa}{n}=\frac{\left(\frac{r(1-\alpha)}{\alpha w_{0}}\right)^{\alpha}}{\frac{p^{F}}{\theta_{1} w_{0}}-\left(\frac{r}{w_{0}}\right)^{\alpha}\left(\frac{\alpha}{1-\alpha}\right)^{1-\alpha}}
$$

As $p^{F}$ declines, this ratio increases. Therefore, TFP increases with the severity of competition.

\subsubsection{Demand Crises}

Just as competition can make full employment and a wage premium for the union impossible, a large decline in demand $\left(\theta_{1}\right)$ can have the same effect. Similar to the competition crisis case, the union adjusts work rules to maximize employment at the competitive wage $w_{0}$.

The demand crisis work rules are:

$$
\kappa^{D C}=\theta^{\frac{1}{\rho}}\left(\frac{A_{1}}{w_{0}}\right)^{\frac{\alpha \rho+1-\alpha}{\rho}}\left((1-\rho)^{\frac{1-\rho}{\rho}}-(1-\rho)^{\frac{1}{\rho}}\right)\left(\frac{\Psi}{r^{\alpha}}\right)^{\frac{1-\rho}{\rho}}
$$

While demand crises reduce work rules, they do not have the same impact on productivity. The ratio of outputs due to labor to labor input is:

$$
\frac{A_{1} n_{1}^{D C}-\kappa^{D C}}{n_{1}^{D C}}=A_{1}-\frac{\left((1-\rho)^{\frac{1-\rho}{\rho}}-(1-\rho)^{\frac{1}{\rho}}\right) \Psi^{\frac{1-\rho}{\rho}}}{\left((1-\rho)^{\frac{1-\rho}{\rho}}-(1-\rho)^{\frac{1}{\rho}}\right) \Psi^{\frac{1-\rho}{\rho}}+\frac{1}{A_{1}}\left(\frac{1-\alpha}{\alpha}\right)^{\alpha}(\Psi(1-\rho))^{\frac{1}{\rho}}}
$$

TFP does not increase with a demand crisis even though work rules decline. The fixed cost generates increasing returns to scale. Producing at a smaller scale for a given fixed cost reduces TFP. While there is less wasted labor input, which increases TFP, employment is falling. The two forces exactly counter each other, leaving TFP unchanged. 


\subsection{Compensation for Work Rules?}

Given that they are inefficient, could the work rules be removed by an agreement between the union and the firm? In this section, I consider compensation in the monopoly case and under competition. The firm will always want to offer a buy-out. There are instances where the union will accept, but not in all cases. Buy-outs fail when they cannot fully employ all union members at a wage above the outside option.

\subsubsection{Monopoly Compensation}

This section considers whether a monopoly firm and union can come to an agreement on removing work rules without competition.

A buy-out is an agreement where each union member receives a lump-sum transfer $T$ and a wage $w_{1}^{B}$ in exchange for setting $\kappa=0$.

For the union to agree to the scheme, each member must receive at least the same total payments (transfers plus wages) as wages under work rules $\left(T+w_{1}^{B} \geq w_{1}^{*}\right)$ and all union members must be employed $\left(n_{1}\left(w_{1}^{B}\right) \geq \bar{n}_{1}\right)$. In addition, the new wage must be higher than the outside option wage to keep members from leaving the union: $w_{1}^{B} \geq w_{0}$.

For the firm to offer compensation, profits must be at least as high as under the work rules case. Profit with compensation is given by:

$$
\pi_{1}^{B}=p\left(w_{1}^{B}\right) y\left(w_{1}^{B}\right)-r K_{1}\left(w_{1}^{B}\right)-w_{1}^{B} n_{1}\left(w_{1}^{B}\right)-T \bar{n}_{1}
$$

Therefore, the firm will offer a buy-out if $\pi_{1}^{B} \geq \pi_{1}$.

The best deal for the firm to offer that the union will accept is $T=w_{1}^{*}-w_{1}^{B}$ and $w_{1}^{B}=w_{1}^{N W R}$, where $w_{1}^{N W R}$ is the maximum wage that employs all union members. Given this compensation scheme, the firm will always want to buy out work rules.

Profit under the buy-out is:

$$
\begin{gathered}
\pi_{1}^{B}=p\left(w_{1}^{N W R}\right) y\left(w_{1}^{N W R}\right)-r K_{1}\left(w_{1}^{N W R}\right)-w_{1}^{N W R} \bar{n}_{1}-\left(w_{1}-w_{1}^{B}\right) \bar{n}_{1} \\
=p\left(w_{1}^{N W R}\right) y\left(w_{1}^{N W R}\right)-r K_{1}\left(w_{1}^{N W R}\right)-w_{1} \bar{n}_{1}
\end{gathered}
$$

The labor payments are unchanged in the buy-out. Therefore, $\pi_{1}^{B} \geq \pi_{1}$ if $p\left(w_{1}^{N W R}\right) y\left(w_{1}^{N W R}\right)-$ $r K_{1}\left(w_{1}^{N W R}\right) \geq p\left(w_{1}^{*}\right) y\left(w_{1}^{*}\right)-r K_{1}\left(w_{1}^{*}\right)$. 
From the firm's solution, we have:

$$
\begin{aligned}
p(w) y(w)-r k_{1}(w) & =\theta_{1}^{\frac{1}{\rho}}\left(\left(\frac{A_{1}}{w}\right)^{1-\alpha} \frac{(1-\rho) \Psi}{r^{\alpha}}\right)^{\frac{1-\rho}{\rho}}-r \theta_{1}^{\frac{1}{\rho}}\left(\left(\frac{A_{1}}{w}\right)^{1-\alpha}\right)^{\frac{1-\rho}{\rho}}\left(\frac{(1-\rho) \Psi}{r^{\alpha}}\right)^{\frac{1}{\rho}}\left(\frac{\alpha}{r(1-\alpha)}\right)^{1-\alpha} \\
& =\theta_{1}^{\frac{1}{\rho}}\left(\frac{A_{1}}{w}\right)^{\frac{(1-\alpha)(1-\rho)}{\rho}}\left(\frac{1}{r^{\alpha}}\right)^{\frac{1-\rho}{\rho}}\left[((1-\rho) \Psi)^{\frac{1-\rho}{\rho}}-\left(\frac{\alpha}{1-\alpha}\right)^{1-\alpha}((1-\rho) \Psi)^{\frac{1}{\rho}}\right]
\end{aligned}
$$

By inspection, this function is decreasing in $w$. (Tedious algebra confirms that the term in brackets is positive.) Since $w_{1}^{N W R}<w_{1}^{*}$, the firm's profit is higher under the buy-out.

Work rules allow the union to push up wages, increasing the firm's marginal costs. While total payments to labor are unchanged with the buy-out, it lowers the marginal cost from labor.

The union will not always accept the buy-out. Recall that the union will accept the buy-out offer if $T+w_{1}^{B} \geq w_{1}^{*}, n_{1}\left(w_{1}^{B}\right) \geq \bar{n}_{1}$ and $w_{1}^{B} \geq w_{0}$. The buy-out was set to satisfy the first two constraints. Therefore, whether the union accepts depends on whether the no work rule wage is greater than the outside option wage. If $w_{1}^{N W R} \geq w_{o}$, a compensation package is possible. If not, it is impossible to have both a wage premium and full employment without work rules. Workers would rather leave the industry than accept below market wages. The union's desire to maintain employment in the industry prevents a deal from being struck.

This situation sets up a conflict between the union and its members. The workers would be just as well off taking the buy-out and leaving the industry. However, the union would cease to exist. It makes sense for union members to set up the union with these preferences, even if they conflict with rank and file preferences in bad times.

There is a trade off between high wages and employment. If the union only cared about wages, it would want to drive up wages as high as possible. Individual workers would be vulnerable to being laid off and receiving no wage premium. Setting up the union to care about employing all members insures that this situation does not occur unless the union is forced to do so.

When will a buy-out not be possible? The no-compensation case $w_{1}^{N W R}<w_{o}$ applies if $\bar{n}_{1}$ is large, since there are too many workers to employ given the level of market power. This condition also applies if the firm has a high degree of market power due to inelastic demand ( $\rho$ large). The firm produces little output at a very high price. Hence, 
there is low demand for (productive) workers and large margins on production. In this case, work rules are important ( $\kappa$ is large) since they allow the (large) monopoly profits to be captured by the union. Removing work rules reduces employment significantly, so wages must fall sharply to counteract the loss of labor demand.

\subsubsection{Competitive Compensation}

I now turn to buy-outs under non-crisis competition. Most of the analysis is similar to the monopoly case: There is a wage premium and all the union members can be employed. The major difference is that the firm is a price taker.

While competition constrains the union, the logic of work rules in unchanged. They still allow the union to set higher wages. Therefore, there are still work rules that the firm would like to buy out.

Proposition 5.3. If the firm faces non-crisis competition $\left(p^{*}=p^{F}>p^{C}\right), w_{1}^{N W R}<w^{*}$.

Proof. By construction, labor demand is the same with $w_{1}^{N W R}$ and $\left\{w_{1}^{*}, \kappa^{*}\right\}$ :

$$
\bar{n}_{1}=\left[\frac{\theta_{1}}{p^{F}}\right]^{\frac{1}{\rho}}\left(\frac{1}{A_{1}}\right)^{1-\alpha}\left(\frac{r(1-\alpha)}{w_{1}^{*} \alpha}\right)^{\alpha}+\frac{\kappa^{*}}{A_{1}}=\left[\frac{\theta_{1}}{p^{F}}\right]^{\frac{1}{\rho}}\left(\frac{1}{A_{1}}\right)^{1-\alpha}\left(\frac{r(1-\alpha)}{w_{1}^{N W R} \alpha}\right)^{\alpha}
$$

Rearranging,

$$
\left[\frac{\theta_{1}}{p^{F}}\right]^{\frac{1}{\rho}}\left(\frac{1}{A_{1}}\right)^{1-\alpha}\left(\frac{r(1-\alpha)}{\alpha}\right)^{\alpha}\left[\left(\frac{1}{w_{1}^{N W R}}\right)^{\alpha}-\left(\frac{1}{w_{1}^{*}}\right)^{\alpha}\right]=\frac{\kappa^{*}}{A_{1}}
$$

Since $\kappa^{*}>0, w_{1}^{N W R}<w^{*}$.

The firm will offer a buy-out if profits are at least as high under the deal as without:

$$
p^{F} y\left(p^{F}\right)-r k_{1}\left(w_{1}^{B}, p^{F}\right)-w_{1}^{B} n_{1}\left(w_{1}^{B}, p^{F}\right)-T \bar{n}_{1} \geq p^{F} y\left(p^{F}\right)-r k_{1}\left(w_{1}^{*}, p^{F}\right)-w_{1}^{*} \bar{n}_{1}
$$

As before, the best deal for the firm to offer that the union will accept is to set wage to maximum wage that employs all union members and transfer the difference: $T=w_{1}^{*}-w_{1}^{B}$ and $w_{1}^{B}=w_{1}^{N W R}$. Under competition, $w_{1}^{N W R}=\left[\frac{\theta_{1}}{p^{F}}\right]^{\frac{1}{\alpha \rho}}\left(\frac{r(1-\alpha) A_{1}}{w_{1} \alpha}\right)\left[\frac{1}{A_{1} \bar{n}_{1}}\right]^{\frac{1}{\alpha \rho}}$.

The firm will still always want to buy out work rules. Labor payments are same under the buy-out. Revenue is also unchanged, since the price is set by the competition. (I am assuming that competition continues to bind under the lower wage: 
$p^{F}<p_{1}^{*}\left(w_{1}^{N W R}\right)$.) The profit condition reduces to $k_{1}\left(w_{1}^{B}, p^{F}\right) \leq k_{1}\left(w_{1}^{*}, p^{F}\right)$. Capital de-

mand is given by $k_{1}\left(w_{1}, p^{F}\right)=\left[\frac{\theta_{1}}{p^{F}}\right]^{\frac{1}{\rho}}\left(\frac{w_{1} \alpha}{A_{1} r(1-\alpha)}\right)^{1-\alpha}$. Since $k_{1}\left(w_{1}, p^{F}\right)$ is increasing in wage $w_{1}$ and wages fall under compensation $\left(w_{1}^{B}<w_{1}^{*}\right)$, the firm's profits are higher with the buy-out.

The binding constraint for the union is whether the new wage is higher than the outside option: $w_{1}^{N W R} \geq w_{0}$. The more binding non-crisis competition is, the easier it is to satisfy this constraint, as shown in the following proposition.

Proposition 5.4. If $p^{F, \prime}<p^{F}$ and $p^{F, \prime}>p^{C}$, then $w_{1}^{N W R, \prime}>w_{1}^{N W R}$.

Proof. By construction, $n_{1}\left(p^{F, \prime}, w_{1}^{N W R, \prime}\right)=n_{1}\left(p^{F}, w_{1}^{N W R}\right)=\bar{n}_{1}$. From the labor demand equation (Equation 5.5):

$$
\left[\frac{\theta_{1}}{p^{F}}\right]^{\frac{1}{\rho}}\left(\frac{1}{A_{1}}\right)^{1-\alpha}\left(\frac{r(1-\alpha)}{w_{1}^{N W R} \alpha}\right)^{\alpha}=\left[\frac{\theta_{1}}{p^{F, I^{\prime}}}\right]^{\frac{1}{\rho}}\left(\frac{1}{A_{1}}\right)^{1-\alpha}\left(\frac{r(1-\alpha)}{w_{1}^{N W R, \prime} \alpha}\right)^{\alpha}
$$

Simplifying:

$$
\left[\frac{p^{F, \prime}}{p^{F}}\right]^{\frac{1}{\rho}}=\left(\frac{w_{1}^{N W R}}{w_{1}^{N W R, \prime}}\right)^{\alpha}
$$

Since $p^{F, \prime}<p^{F}$, this expression implies that $w_{1}^{N W R, \prime}>w_{1}^{N W R}$.

More competition (a lower price) means that output is higher. Therefore, labor demand is higher for a given wage so the wage need not fall as much to employ all union members. As a result, more competition means that there are fewer work rules to buy out.

When there is crisis competition, no buy-out is possible. Work rules are the only thing keeping the union in business. Wages are already pushed down to the outside option wage $w_{0}$, so it cannot fall any further without all union members exiting the industry.

\subsubsection{Other types of buy-outs}

In the buy-out deals discussed above, all workers are retained on the job. Why aren't excess workers pensioned out instead of kept at work? In the model, the union's preferences prevent such a deal from occurring. As discussed above, workers have an incentive 
to set up unions in this way to protect members from being pushed out of their share of the surplus.

If workers are paid off but retain union membership, two classes of workers are created: workers and pensioners. If there is a significant stock of members who do not work, there may be a conflict over what goals the union should pursue. Retirees will want high benefits and have little interest in high wages or maintaining employment while current workers will weight the latter goals more highly. This conflict has occurred. The United Mine Workers developed a situation where a majority of its members did not work as miners. Labor contracts had to be ratified by a group where most members did not work.

In addition, there are frictions that prevent such deals from occurring. It can be difficult to commit to paying prime aged workers who are not working or working other jobs. The JOBS program, which paid auto workers most of their wages even if they did not work, was eliminated by Congress when GM was taken over by the U.S. government due to its political unpopularity (Michaels 2009). Firms may have difficulty committing to deals that are politically unpopular and unions may be suspicious that the firms will use public pressure to get out of their obligations in the future.

\subsection{Resistance to New Technology}

If a new technology is available, the union will always allow the adoption new vintages. However, the presence of work rules can induce resistance to adopting new vintages unless the union has control over how the new technology is operated. Without work rules, new technology is supported by both the union and firms since it increases profits for firms and wages and labor demand for the union. These forces are still in operation with work rules, but there is a countervailing force. New technology weakens the impact of work rules, reducing the demand for labor. In some cases, the fall in labor demand from the work rule weakening force is stronger than the increase in labor demand from the new technology.

To examine this situation, suppose that the monopoly firm wished to adopt a new technology under wages and work rules implied by the old technology. The following proposition establishes conditions under which the union would block adoption. 
Proposition 5.5. For any $A_{1}^{\prime}=\gamma A_{1}$, where $\gamma>1$,

1. For every $\alpha$, there exists $\bar{\rho}$ such that $n_{1}\left(w_{1}^{*}, \kappa^{*}, A_{1}^{\prime}\right)<n_{1}\left(w_{1}^{*}, \kappa^{*}, A_{1}\right)$ for all $\rho>\bar{\rho}$

2. For every $\rho$, there exists $\bar{\alpha}$ such that $n_{1}\left(w_{1}^{*}, \kappa^{*}, A_{1}^{\prime}\right)<n_{1}\left(w_{1}^{*}, \kappa^{*}, A_{1}\right)$ for all $\alpha>\bar{\alpha}$

Proof. Using the labor demand (Equation 5.10), the condition for the new technology to reduce labor demand is:

$$
\begin{aligned}
\left(\gamma A_{1}\right)^{\frac{(1-\alpha)(1-\rho)}{\rho}}\left(\frac{1}{w_{1}^{*}}\right)^{\frac{\alpha \rho+1-\alpha}{\rho}} \theta_{1}^{\frac{1}{\rho}}\left(\frac{1}{r^{\alpha}}\right)^{\frac{1-\rho}{\rho}}\left(\frac{1-\alpha}{\alpha}\right)^{\alpha}(1-\rho)^{\frac{1}{\rho}} \Psi^{\frac{1}{\rho}}+\frac{\kappa^{*}}{\gamma A_{1}}< \\
\left(A_{1}\right)^{\frac{(1-\alpha)(1-\rho)}{\rho}}\left(\frac{1}{w_{1}^{*}}\right)^{\frac{\alpha \rho+1-\alpha}{\rho}} \theta_{1}^{\frac{1}{\rho}}\left(\frac{1}{r^{\alpha}}\right)^{\frac{1-\rho}{\rho}}\left(\frac{1-\alpha}{\alpha}\right)^{\alpha}(1-\rho)^{\frac{1}{\rho}} \Psi^{\frac{1}{\rho}}+\frac{\kappa^{*}}{A_{1}}
\end{aligned}
$$

Putting in equilibrium wage $w_{1}^{*}$ and work rules $\kappa^{*}$ and simplifying, the condition becomes:

$$
(\gamma-1)\left[\frac{1}{1-\rho}-1\right]>\left(\gamma^{\frac{\alpha \rho+1-\alpha}{\rho}}-\gamma\right)\left[\frac{\left(\frac{1-\alpha}{\alpha}\right)^{\alpha}}{\left(\frac{\alpha}{1-\alpha}\right)^{1-\alpha}+\left(\frac{1-\alpha}{\alpha}\right)^{\alpha}}\right]
$$

The limit of the RHS of Equation 5.19 is infinity as $\rho \rightarrow 1$ for a given $\alpha$ while the limit for the LHS is zero. Therefore, the condition is true for sufficiently large $\rho$.

The limit of the LHS of Equation 5.19 is zero as $\alpha \rightarrow 1$ for a given $\rho$.

As we can see from the labor demand equation, new technology has two effects. On one hand, it increases demand for productive labor by lowering marginal costs (and consumer prices). On the other, it weakens the impact of work rules. Work rules are a fixed cost and new technology reduces the relative importance of the fixed cost in production. The work rules effect will dominate if market power is high ( $\rho$ is large) and when the technology is capital intensive ( $\alpha$ is large).

As noted above in the discussion of compensation, when market power is high, the firm produces little output and demands little labor to produce output. New technology does not increase the demand for productive labor much. On the other hand, there are many work rules ( $\kappa$ is high). Since most labor demand is non-productive labor, weakening work rules has the stronger effect on overall labor demand. This finding is consistent with Dowrick \& Spencer (1994), who find that unions that care about employment will block new technology when demand is inelastic. 
When the firm faces competition, new technology always reduces employment under the old wages and work rules. Labor demand is given by:

$$
n_{1}\left(w_{1}, \kappa, A_{1}\right)=\frac{1}{A_{1}^{1-\alpha}}\left[\frac{r(1-\alpha)}{\alpha w_{1}}\right]^{\alpha}+\frac{\kappa}{A_{1}}
$$

Labor demand is strictly decreasing in productivity $A_{1}$. The weakening of the work rules effect is the same as in the monopolist case. However, the monopolist does not adjust prices downward in response to lower costs. There is no increase in production with new technology. Therefore, increasing productivity just reduces the need for productive labor.

The union will always accept the new technology in equilibrium since it can adjust the work rules (increase $\kappa$ ) to compensate for the fall in labor demand. Just increasing wages is insufficient to garner union support, since that change will not lead to full employment for union members. In fact, raising wages exacerbates the problem by reducing labor demand further.

This finding is consistent with the data. If the union can dictate work rules without restriction, it is willing to adopt the new technology. An example is the bulk loading witnesses in Pacific ports discussed above. The longshoremen's union accepted the new bulk loading methods without a fight since it could dictate minimum gang size. If the union could not increase work rules to compensate for the loss of employment, under the conditions of the proposition, the union would oppose the new technology.

Conversely, the union requires unproductive techniques only when it does not have strong control of the use of technology. At the same time that it was allowing bulk loading, the union required that goods on pallets be removed and re-palleted in the port by longshoremen. The union faced a jurisdictional battle with the Teamsters over which union's workers were allowed to place goods on pallets. As a compromise, both union's workers did the job. The union was not opposed to pallets, but want to retain loading work for their workers. In Portland, an arbitrator ruled that the goods were not to be removed from the pallet. The employer just paid for the extra hours it would have take to do so (Hartman 1969). In fact, the original Luddite uprising in England was more about jurisdictional issues (who was allowed to use new machinery and how it was used) than a protest against new technology itself. Damaging equipment was a tactic to get 
recognition of workers' demands (Conniff 2011).

\section{Conclusion}

This paper gives an explanation for genuinely wasteful work rules in non-competitive industries. Adding non-productive paid work hours allows workers to maintain employment while keeping wages high.

While the motivating examples have generally been formal work rules in union contracts, the logic of the analysis extends to management. In good times, firms do not fight to minimize cost. Borenstein \& Farrell (2007) find that stock prices of gold mining firms do not rise by the full value of their gold stocks when gold prices rise. Stock traders believe that some of the increased value will be dissipated.

Senior executives often appear to prefer not to get rid of incumbent staff, just as unions like to keep their members employed. They follow J.R. Hicks's famous phrase that the "best of all monopoly profits is a quiet life" (Hicks 1935). Monopoly spares them the unpleasant process of firing people. Strohmeyer (1994) notes that Bethlehem Steel's management was significantly overstaffed. If a manager was underperforming, a new one was added without removing the old one. When competition intensified in the 1980s, management headcount was significantly reduced. Bertrand \& Mullainathan (2003) find evidence that executives protected by anti-takeover laws care about white collar workers more than shareholders. White collar workers enjoy higher wages and are more secure in their employment. They are also less productive. These results match those of the model. This process may explain why competition improves managerial as well as labor productivity (Van Reenen 2010). 


\section{References}

Acemoglu, Daron (2003), 'Why not a political Coase theorem?: Social conflict, commitment, and politics', Journal of Comparative Economics 31, 620-652.

Acemoglu, Daron, Philippe Aghion \& Gianluca Violante (2001), 'Deunionization, technical change, and inequality', Carnegie-Rochester Conference Series on Public Policy 55(1), 229-264.

Aghion, Phillipe \& Rachel Griffith (2005), Competition and Growth: Reconciling Theory and Evidence, MIT Press, Cambridge.

Bai, Yan \& Berthold Herrendorf (2008), What is the relationship between competition and productivity?, mimeo, Arizona State University.

Bastos, Paulo \& Peter Wright (2010), Exchange rates and wages in unionised labour markets, Globalisation and Labour Markets Working Paper 2010-15, University of Nottingham.

Bertrand, Marianne \& Sendhil Mullainathan (2003), 'Enjoying the quiet life? corporate governance and managerial preferences', Journal of Political Economy 111(5), 10431075 .

Borenstein, Severin \& Joseph Farrell (2007), 'Do investors forecast fat firms?: Evidence from the gold-mining industry', RAND Journal of Economics 38(3), 626-647.

Bridgman, Benjamin, Igor Livshits \& James MacGee (2007), 'Vested interests and technology adoption', Journal of Monetary Economics 54(3), 649-666.

Bridgman, Benjamin, Victor Gomes \& Arilton Teixeira (2011), 'Threatening to increase productivity: Evidence from Brazil's oil industry', World Development 39(8).

Chari, V.V. \& Hugo Hopenhayn (1991), 'Vintage human capital, growth, and the diffusion of new technology', Journal of Political Economy 99, 1142-1165.

Conniff, Richard (2011), 'What the Luddites really fought against', Smithsonian . 
Desmet, Klaus \& Stephan L. Parente (2010), 'Bigger is better: Market size, demand elasticity and innovation', International Economic Review 51(2), 319-333.

Dowrick, Steve \& Barbara J. Spencer (1994), 'Union attitudes to labor-saving innovation: When are unions Luddites?', Journal of Labor Economics 12(2), 316-344.

Dunne, Tim, Shawn Klimek \& James Schmitz (2009), Does foreign competition spur productivity?: Evidence from post WWII U.S. cement manufacturing, Manuscript, Federal Reserve Bank of Minneapolis.

Eberts, Randall \& Joe Stone (1991), 'Unionization and cost of production: Compensation, productivity, and factor-use effects', Journal of Labor Economics 9(2), 171185.

Finlay, William D (1987), 'Industrial relations and firm behavior : Informal labor practices in the West Coast longshore industry', Administrative Science Quarterly 32(1).

Finlay, William D (1988), Work on the waterfront: Worker power and technological change in a West Coast port, Temple University Press, Philadelphia.

Freeman, Richard B. \& Morris Kleiner (1999), 'Do unions make enterprises insolvent?', Industrial and Labor Relations Review 52, 510-527.

Galdon-Sanchez, Jose E. \& James A. Schmitz (2002), 'Competitive pressure and labor productivity: World iron-ore markets in the 1980s', American Economic Review 92(4), 1222-1235.

Greenberg, David (1968), 'Deviations from wage-fringe standards', Industrial and Labor Relations Review 21, 197-209.

Hartman, Paul T. (1969), Collective Bargaining and Productivity: The Longshore Mechanization Agreement, University of California Press, Berkeley.

Henle, P (1973), 'Reverse collective bargaining?: A look at some union concession situations', Industrial and Labor Relations Review 26, 956-968. 
Herrendorf, Berthold \& Arilton Teixeira (2010), 'Barriers to entry and development', International Economic Review 52(2), 573-602.

Hicks, J.R. (1935), 'Annual survey of economic theory: The theory of monopoly', Econometrica 3(1), 1-20.

Hoerr, John P. (1988), And the Wolf Finally Came: The Decline of the American Steel Industry, University of Pittsburgh Press, Pittsburgh.

Holmes, Thomas, David Levine \& James A. Schmitz (2008), Monopoly and the incentive to innovate when adoption involves switchover disruptions, Working Paper 13864, NBER.

Holmes, Thomas \& James A. Schmitz (1995), 'Resistance to new technology and trade between areas', Federal Reserve Bank of Minneapolis Quarterly Review 19, 2-17.

Holmes, Thomas \& James A. Schmitz (2010), Competition and productivity: A review of the evidence, Staff Report 439, Federal Reserve Bank of Minneapolis.

Holmes, Thomas \& Julia Thornton Snider (2011), 'A theory of outsourcing and wage decline', American Economic Journal: Microeconomics 3(2), 38-59.

Ichniowski, Casey (1984), Ruling out productivity?: Labor contract pages and plant performance, Working paper, NBER.

Johnson, George E. (1990), 'Work rules, featherbedding, and Pareto-optimal unionmanagement bargaining', Journal of Labor Economics 8(1), S237-S259.

Kahn, Charles M. \& Patricia B. Reagan (1993), 'Introducing work rules into models of wage-employment contracts', Quarterly Review of Economics and Finance 33(3), 217-231.

Kocherlakota, Narayana (2001), Building blocks for barriers to riches, Staff Report 288, Federal Reserve Bank of Minneapolis.

Krusell, Per \& Jose-Víctor Ríos-Rull (1996), 'Vested interests in a positive theory of stagnation and growth', Review of Economic Studies 63, 301-29. 
MaCurdy, Thomas E. \& John H. Pencavel (1986), 'Testing between competing models of wage and employment determination in unionized markets', Journal of Political Economy 94(3), S3-S39.

Michaels, Ryan (2009), Layoff costs and dynamic labor demand: Evidence from U.S. auto industry job security agreements, mimeo, University of Michigan.

Mitchell, Matthew \& Andrea Moro (2006), 'Persistent distortionary policies with asymmetric information', American Economic Review 96, 387-393.

Mitchell, Merwin \& Joe Stone (1992), 'Union effects on productivity: Evidence from western U.S. sawmills', Industrial and Labor Relations Review 46(1), 135-145.

Olson, Mancur (1982), The Rise and Decline of Nations, Yale University Press, New Haven.

Parente, Stephen \& Edward C. Prescott (1999), 'Monopoly rights: a barrier to riches', American Economic Review 89, 1216-33.

Parente, Stephen \& Edward C. Prescott (2000), Barriers to Riches, MIT Press, Cambridge.

Pissarides, Christopher (1986), 'Trade unions and the efficiency of the natural rate of unemployment', Journal of Labor Economics 4(4), 582-595.

Schmitz, James A. (2005), 'What determines productivity?: Lessons from the dramatic recovery of the U.S. and Canadian iron ore industries following their early 1980s crisis', Journal of Political Economy 113, 582-625.

Strohmeyer, John (1994), Crisis in Bethlehem: Big Steel's Struggle to Survive, University of Pittsburgh Press, Pittsburgh.

Van Reenen, John (2010), Does competition raise productivity through improving management quality?, Discussion Paper 1036, Centre for Economic Performance.

Vasconcelos, Helder (2005), 'Tacit collusion, cost asymmetries, and mergers', Rand Journal of Economics 36(1), 39-62. 
Vives, Xavier (2008), 'Innovation and competitive pressure', Journal of Industrial Economics 56(3), 419-469. 